\title{
Six Levels of Indonesian Primary School Students' Mental Model in Comprehending the Concept of Integer
}

\author{
Anita Dewi Utami \\ Dr. candidate, Graduate School, Mathematics Education, Universitas Negeri Malang, \\ East Java, Indonesia, anita.dewi.1603119@students.um.ac.id \\ Cholis Sa'dijah \\ Prof., corresponding author, Graduate School, Mathematics Education, Universitas \\ Negeri Malang, East Java, Indonesia, cholis.sadijah.fmipa@um.ac.id

\section{Subanji} \\ Assoc. Prof., Graduate School, Mathematics Education, Universitas Negeri Malang, \\ East Java, Indonesia, subanji.fmipa@um.ac.id

\section{Santi Irawati} \\ Assoc. Prof., Mathematics, Universitas Negeri Malang, East Java, Indonesia, \\ santi.irawati.fmipa@um.ac.id
}

A pivotal information about the structure of students' comprehension underlying from which the knowledge is gained can be identified through the mental model. This study aimed at describing the six levels of students' mental model in comprehending the concept of the integer. The subject of this research was 40 students consisting of 20 students from the second graders of primary school and 20 students from the third graders of primary school. The subject was taken from two classes in order to meet the whole levels of the mental model. The subject of the research was given a test to know their comprehension of the concept of the integer. From the subject, there were 6 students who were interviewed because they have already fulfilled the six levels of the mental model. To guarantee the validity and reliability of the research, the triangulation technique was done by comparing the video recording of the interview with the results of the test. The results reveal that there are six levels of students' mental model in comprehending the concept of integer, i.e. pre-initial mental model, initial mental model, the transition 1, synthetic mental model, the transition 2, and formal mental model.

Keywords: mental model, concept of integer, positive integers, negative integers, primary school students

Citation: Utami, A. D., Sa'dijah, C., Subanji, \& Irawati, S. (2018). Six Levels of Indonesian Primary School Students' Mental Model in Comprehending the Concept of Integer. International Journal of Instruction, 11(4), 29-44. https://doi.org/10.12973/iji.2018.1143a 


\section{INTRODUCTION}

A pivotal information about the structure of students' comprehension underlying from which the knowledge is gained can be identified through the mental model (Vosniadou $\&$ Brewer, 1992). The individual mental model is a domain in which new information is put in the knowledge base, thus mental model can inhibit the acquisition process of knowledge in a way which is similar to belief and prejudice. Someone makes a change in his/her belief based on the instruction of an adult, but a person still lacks a scientific theory. Further Özdemir \& Clark (2007) describes the instruction of adults directing children to build a synthetic mental model that is still consistent with scientific theory. However, the synthetic mental model implies that students begin to synthesize scientific theory with their initial theory.

The mental model can show students' way of thinking. This had been studied by several researchers (Senge, 2004; Solaz-Portoles \& Loppez, 2007 \&; Wang, 2007). Senge (2004) describes the mental model as a person's internal image of thinking and the image that limits a person to action. Solaz-Portoles \& Loppez (2007) further explains that the mental model is used to explain the individual reasoning process in solving the problem of syllogism. A person is often unaware to realize his or her own mental model, or the influence of a mental model on one's behavior. While Wang (2007) states that research in education generally requires research studying the mental model by focusing on the conceptual aspect.

Several studies on mental models show that many students have very simple mental models of chemical phenomena, such as atomic and molecular models described as solids, but do not always have the ability to build more complex mental models (Chittleborough \& Treagust 2007; Coll, 2008, Sunyono, et al, 2011; Guzel \& Adadan, 2013; Sunyono \& Yulianti, 2015; Sunyono, et al., 2015). Chittleborough \& Treagust (2007) state that most students prefer to use their mental models in simple representation phenomena. Even post-graduate students prefer a simple and realistic mental model (Coll, 2008). Sunyono, et al (2011) describe students' mental models tend to be at macroscopic and symbolic levels, as well as their sub-microscopic level of mental models not yet well developed due to difficulties in interpreting sub-micro phenomena. While Guzel \& Adadan (2013) state that students have a very simple mental model of chemical phenomena, such as atomic and molecular models and lack the ability to build more complex mental models. While the mental model of new university students in understanding the concept of atomic structure is in terms of initial knowledge that has been studied (Sunyono, et al, 2015).

Some researchers study personal mental models by grouping them based on several characteristics. The research on the grouping of mental models has been done by several researchers (Barsalou, 1992, Vosniadou, 1992; Park \& Light, 2009; Jaber \& Boujaoude, 2012; Bofferding, 2014; Ahi, 2016). Barsalou (1992) divides the level of the characteristic of the mental model into two parts: the structural mental model and the conceptual mental model. Vosniadou (1992) classifies the mental model into three: the initial, synthetic, and formal mental models. Meanwhile, Park \& Light (2009) classify the mental model into 5 categories: the initial formless or unclear mental model, the 
second intermediate_1 mental model, the third intermediate_2 mental model, the fourth intermediate_3 mental model and the target mental model. Jaber and Boujaoude (2012), classify the characteristics of the mental model into three categories: high, medium, and low mental models. In contrast, Bofferding (2014) conducted a research by developing the classification of mental models introduced by Vosniadou (1992) into 5 mental models by inserting transition 1 between the initial and synthetic mental models, and transitions 2 between synthetic and formal. While Ahi (2016) studies the child's mental model of environmental concepts in the desert and found seven different categories of desert concepts.

Tasker \& Dalton (2006) state that a mental model is the transformation of external representation into the internal representation. When memory processes a perception, it is possible that students' perceptions are incorrect in understanding a concept that may cause cognitive impediments. An example of a misconception of student concepts is that when students understand the initial concept of numbers as the results obtained from counting objects in a set of objects, this kind of understanding will cause cognitive impediments when students will understand the concept of negative integers (Bishop, et al, 2014 ). The use of the inappropriate term or understanding is one of the problems that need to be improved in learning mathematical concepts (Mardiyana, Susiswo, \& Hidayanto, 2016). Vlassis (2008) also suggests that the use of 'minus' signs in very limited contexts may also affect students' conceptions of understanding.

Teaching the concept of integers with real context can help students understand the integers. Akyus \& Stephan (2012), state that students can successfully draw their experience with assets, debt, and prices to create their understanding of the addition and subtraction of negative integers. While Ural \& Buldur (2016) reveal that students can write the problems correctly in the context of debt, owe, and loss of money. In addition, Shutler (2017) states that the banking model is the ideal tool for visualizing positive and negative numbers. Utami \& Parta (2017) indicate that students understand the concept of negative numbers in terms of debt and borrowing. In reality, however, teachers do not use some kind of problems to teach addition and subtraction of integers (Enzinger \& Tobias, 2015). Other facts also indicate that most students regard mathematics as a frightening topic so they have difficulty in learning mathematics (Sumantri \& Satriani, 2016).

The concept of integers is still difficult for students. Research by Karantzis (2010) shows that students tend to have difficulty in operating subtraction rather than addition. Bofferding \& Enzinger (2017) describe students bridging the logical reasoning that they already have towards the logic of spherical thinking as a solution to the problem of subtraction associated with negative integers. In fact, most students are still difficult in solving mathematical problems, whereas problem-solving skills are the basic skills which students must possess (Kaya, et al, 2014). While Bishop, et al, (2014) show that students still experience barriers to their understanding of the concept of negative integers. One of the barriers experienced by students is also caused by mistakes of teachers who only focus on the operations of students without teaching them from the conceptual perspective (Karadeniz, et al, 2017). 
Research on the students' mental model in understanding the concept of negative integers has been investigated by Bofferding (2014). Bofferding found five mental models of students on their understanding of integers, the initial mental model, transition 1 , the synthetic mental model, the transition 2 , and the formal mental model. Researchers intend to develop the level of students' mental models in understanding the concept of integers. This becomes pivotal because mental model construction is the core of meaningful learning, wherein understanding, and reasoning how a system works, an individual needs to construct a mental model in his or her brain against the system it encounters (Abdullah, 2006). In addition, Chiras (2008), states that the mathematical achievement of students is an excellent predictor of the quality of their mental models. The mental model of students can be known by looking at the thinking process of students in constructing a concept. Knowledge will be formed if students are actively constructing (Subanji, 2015). For that, the researcher intends to study more deeply about the addition of the level of students' mental models in understanding the concept of integers.

\section{METHOD}

\section{Research Subject}

This is a qualitative research. The subject of this study was 40 Indonesian primary school students consisting of 20 students of the second graders and 20 students of the third graders. The reason for choosing a subject from two levels of primary school was to meet the overall level of the mental model. The subjects chosen for interview are subjects who meet the criteria as shown in Table 1.

\section{Table 1}

The Criteria of Student Mental Model in Understanding Integers (Bofferding, 2014)

\begin{tabular}{|c|c|}
\hline Main Category & Student's Understanding \\
\hline The Initial Mental Model & The child understands the value of a negative integer equal to a positive integer. \\
\hline Transitional Mental Model I & The child is able to compare the values of positive integers and negative integers. \\
\hline Synthetic Mental Model & The child is able to compare the values of two negative integers. \\
\hline $\begin{array}{l}\text { Transitional Mental Model } \\
\text { II }\end{array}$ & $\begin{array}{l}\text { The child has not been consistently in sorting the whole integers. The child is } \\
\text { only able to sort positive integers. }\end{array}$ \\
\hline Formal Mental Model & $\begin{array}{l}\text { The child is able to sort positive and negative integers (the child understands the } \\
\text { symmetry of integers). }\end{array}$ \\
\hline
\end{tabular}

Based on answers, 40 students were grouped into five levels of mental models in accordance with their understanding of integers as shown in Table 1, following the distribution of the number of student responses shown by Table 2 .

Table 2

The Number of Students at Each Level of Mental Model

\begin{tabular}{ll}
\hline The Level of Mental Model & The Number of Students \\
\hline Pre-Initial Mental Model (PMM) & 4 students \\
\hline The Initial Mental Model (IMM) & 8 students \\
\hline Transitional Mental Model I (TMM I) & 7 students \\
\hline Synthetic Mental Model (SMM) & 8 students \\
\hline Transitional Mental Model II (TMM II) & 7 students \\
\hline Formal Mental Model (FMM) & 6 students \\
\hline
\end{tabular}


Based on the six levels of mental model shown by Table 2, one student of the each level was selected for interview. The selected subjects based on the highest students' communication skills of the each level, namely Subject 1 (S1) represent PMM, Subject 2 (S2) represent IMM, Subject 3 (S3) represent TMM I, Subject 4 (S4) represent SMM, Subject 5 (S5) represent TMM II, and Subject 6 (S6) represent FMM.

\section{Data Collection}

In this research, the data was taken from the test and interview. The researcher made a scoring rubric before giving a test on the subject of the study. Sa'dijah (2009) explains that there are two kinds of scoring rubric, i.e. holistic scoring rubric (describing performance quality for each level) and analytical scoring rubric (giving value for task component). The scoring rubric used in this research was holistic scoring rubric. This is because the holistic scoring rubric is to assess the overall work of the students based on quality, while it also emphasizes the process of thinking and communication in mathematics (Sa'dijah, 2009).

Researchers also observed the activities of students who were completing the test questions provided. Furthermore, researchers conducted interviews with the selected research subjects. The data in this study obtained from the written answers obtained after students completed the problem of understanding the concept of integers and interviews were conducted by researchers. In this study, each interview was recorded by using a video and students' written test results were collected. To ensure the validity and reliability of the research, data analysis was performed by triangulation through the display of data from the video and comparing it with the students' written test data. (Golafshani, 2003; Mathison, 1988).

\section{Data Analysis}

To analyze the interview results, the researchers watched the interview video twice. When the researchers watched the video recording for the first time, they carefully paid attention to the relationship between the students' written test results and related literature. In the second view, the researchers looked in detail at the video interviews and the students' written test results to determine each category of the mental model level. After the categories of each mental model were determined, the next step was to begin to process the data according to the mental model levelling. This categorization is an important step in data analysis because it facilitates meaningful data interpretation. This categorization emerges through a literature review, identifying each interview answer and the students' written test that represents related concepts in the literature.

\section{FINDINGS}

The following are the results of research that researchers will describe and explain each answer that shows the level of mental models of students in understanding the concept of integers. The student at the pre-initial mental model level can be seen when he/she thinks the number on the left of 'one' is like two, three, four, and so on (as well as the positive integer to the right of number one). This can be shown in the following student's answers. 
Question: Look at the following number line below! Fill in the blank box numbers!

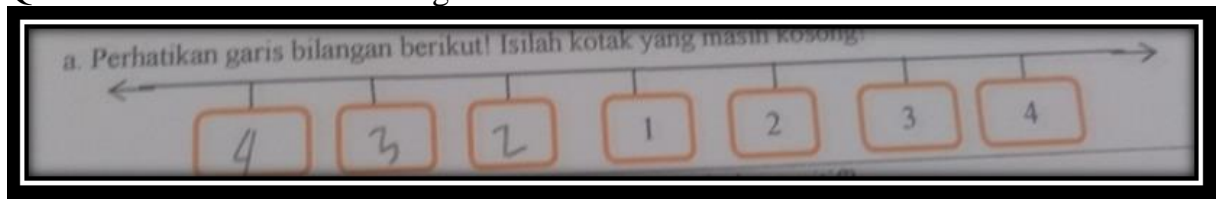

Figure 1

The Answer of Student 1 (S1)

Based on the answer, the student does not understand the number of zeros and negative integers. When the researchers asked why he answered the number two on the left of number one, he explained that after the number one he knew that it is number two. This can be shown in the following interview transcript. ( $R$ is researcher).

$R:$ "Why are you responding to that number?" (The researcher is pointing to number 2 on the answer sheet).

S1:"Yes, it is because, after number one, it should be number two, Mom".)

$P$ : "So, what's the difference between number 2 here (pointing number 2 in the right side of number 1) with the one on it (pointing number 2 in the left side of number $1)$ ?

P: "Yes, it's the same, I know that number is only 1, 2, 3, 4, and so on."

The second level is the initial mental model. The student at the initial mental model already knows that the number on the left of 'one' is zero. The student considers the value of the negative number to be the same as the positive number (the student considers the number to the left of zero as well as the positive integers). This can be shown in the following student's answer.

Question: Look at the following number line below! Fill in the blank box numbers!

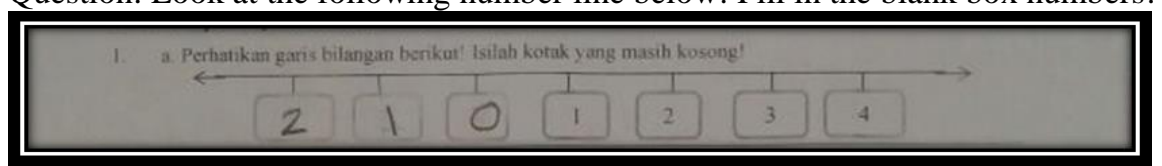

Figure 2

The Answer of Student 2 (S2)

Based on the answer, the student can fill the empty box on the left of the number 'one' with 'zero', but in the next boxes on the left of 'zero', he wrote number 'one and two'. When the researchers asked the reason why he wrote so, he simply answered that the number he knows to the left of 'zero' is the same as the number which is on the right of 'zero'. This can be shown in the following interview transcript. ( $R$ is researcher).

$R$ : "Why do you answer like that?" (Researcher is pointing to the number ' 1 ' in the left of ' 0 ').

S2: 'Yeah, That's right, mom. The number 'one' here (while pointing to number ' 1 ' on the left of 'zero') is the same as the number 'one' here (while pointing to the number ' 1 ' on the right of 'zero'). 
$R$ : "What's the difference between this one (pointing to the number ' 1 ' to the left of 'zero') and this one (pointing to the number '1' to the right of 'zero')?"

S2: "Yes, There is no difference, mom. They are same, 0, 1, 2, 3, the order is like that".

The third level is the transitional mental model I. The Students at this level are able to compare the values of negative integers and positive numbers. The students at this level already understand that the value of a positive integer is greater than a negative integer, but the students have not been consistently correct in comparing the values of positive integers and negative integers. The students are unable to compare the values of two negative integers. This can be shown in the following student answers.

Question: Ana got score "4" and Ani got "-7", who is the winner? Elaborate your reasons!

Question: Arka got score "-6" and Ani got "-3", who is the winner? Elaborate your reasons!

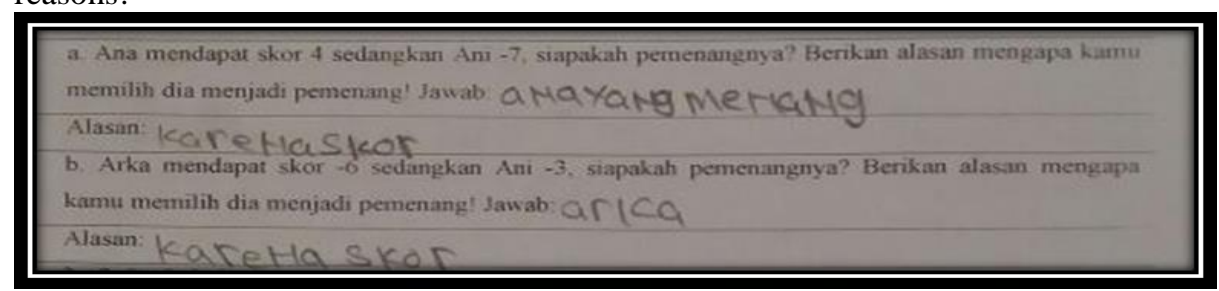

Figure 3

The Answer of Student 3 (S3)

Based on the answers, it can be seen that the student is correct with the answer that Ana won the game because Ana got (4) while Ani got (-7). Based on that answer, the student has been able to compare that the value of a positive integer is greater than the value of a negative integer, but he has not been able to compare between (-6) and (-3). This can be seen when he answered that the winner is Arka who scores (-6). The student at this level understands the value of $(-6)$ is greater than $(-3)$ because he considers that 6 is greater than 3 . He does not see a minus sign in front of the number. He thinks that the determination of a negative integer value is equal to a positive integer. This can be shown in the following interview transcript. ( $R$ is researcher).

$R$ : "Why is number 4 greater than -7?)

S3: "It is because 4 is a positive number, while -7 is a negative number, mom."

$R$ : "Is the rule like that?"

S3: "Yes, mom. My teacher said so."

R: "How about this one? Why is -6 greater than -3 ?"

S3: "It is because 6 is greater than 3."

$R$ : "What sign is this, dear? (While pointing to the minus sign in front of 6 and 3 ").

S3: "it's a minus sign, mom." 
$R$ : "How do you read these? (pointing to -6 and -3$)$."

S3: "It's negative 6 and negative 3."

R: "Then, is it the same or different with between 6 and -6; 3 and -3."

S3: "Of course, they are different. The one is without minus sign and another without it. But, the case is 6 is greater than 3."

The fourth level is a synthetic mental model. Students at this level are consistent in comparing two numbers. The student has been able to compare positive integers and negative integers, as well as to compare two negative numbers precisely. This can be seen from the following student's answers.

Question: There are two children who play a game and try to get the best/highest score.

a. Ana got score " 4 " and Ani got "-7", who is the winner? Elaborate your reasons!

b. Arka got score "-6" and Ani got "-3", who is the winner? Elaborate your reasons!

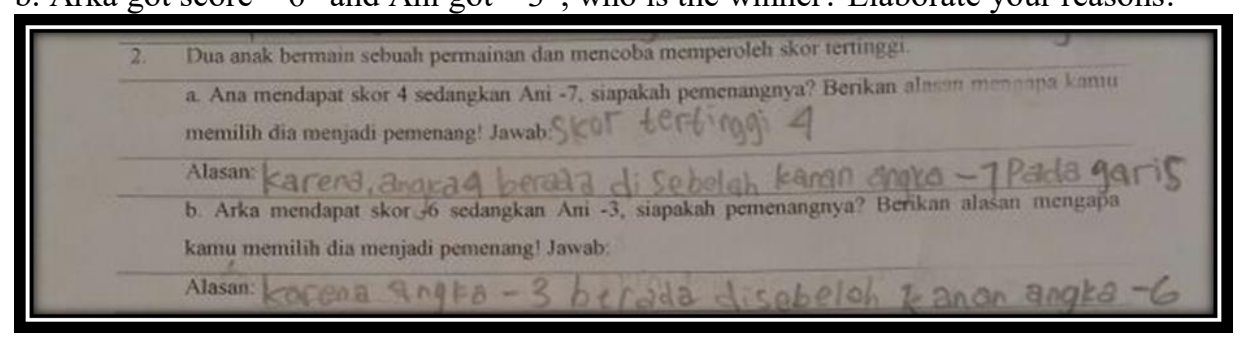

Figure 4

The Answer of Student 4 (S4)

Based on the answer, it can be seen that the student has correctly answered that 4 is greater than -7 and also -3 is greater than -6 . He has already understood that the positive number is greater than the negative number. Students at this level have been able to compare two negative numbers. He assumes that the smaller the negative number, the greater the value. This can be shown in the following interview transcript. $(R$ is researcher).

$R$ : "Why is 4 greater than -7?"

S4: "It is because 4 is a positive number, while -7 is a negative number."

$R:$ :Is the rule like that?"

S4: "Yes, mom. Positive numbers are greater than negative ones.

R: "How about this? Why is -3 greater than -6?"

S4: "It is because -3 is located on the right side of -6. My teacher said that if the number is located on the right side, the value is greater."

The fifth level is the transitional mental model II. The students at this level have not been consistent in ordering negative integer values. Students at this level are already able to sequence positive integers, but still wrong in sorting negative integers. This can be shown in the following student's answers.

Question: Put the numbers below in a correct order (from the biggest to the smallest)! 


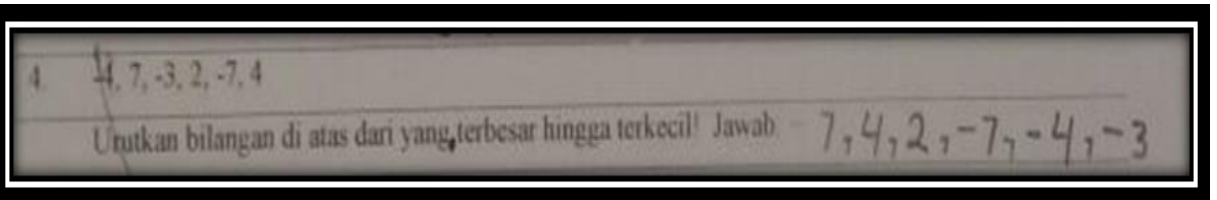

Figure 5

The Answer of Student 5 (S5)

Based on the student's answer, it shows that the student is correct in sorting positive integers from the largest to the smallest, but he is wrong in determining the largest number to the smallest of negative integers. When the researcher asks the reason why he did so, he answered that 7 is greater than 4 and 3. When the researcher asked about the minus sign following that number, he simply answers no sign of it. This can be shown in the following interview transcript. ( $R$ is researcher).

$R$ : "Why did you order the numbers like that? (pointing to -7, -4, and -3)."

S5: "That's true, mom. 7 is greater than 4 and 3."

R: "How about the minus sign? (pointing the minus signs preceding those numbers)"

S5: "It doesn't matter, mom. The point is 7 is greater."

$R$ : "What do you mean, dear?"

S5: "It means that the sign has no effect. The point is the value is greater."

The sixth level is a formal mental model. Students' these levels are consistent in sorting negative integer values as well as positive integer values. Students at this level are capable of serving the nature of positive integer and negative integers. This can be shown in the following student's answers.

Question: Put the numbers below in a correct order (from the smallest to the biggest)!

\section{Untkan bilangan di atas dant yang lexkecil hirigea terbesar Jawab $-9,-5,-3,0,2,3,8$}

Figure 6

The Answer of Student 6 (S6)

Question: The temperature of a fluid substance is $-3^{\circ}$ Celsius. If the substance is heated, the temperature raises to $9^{\circ}$ Celsius. How many degrees is the rise of the fluid substance?

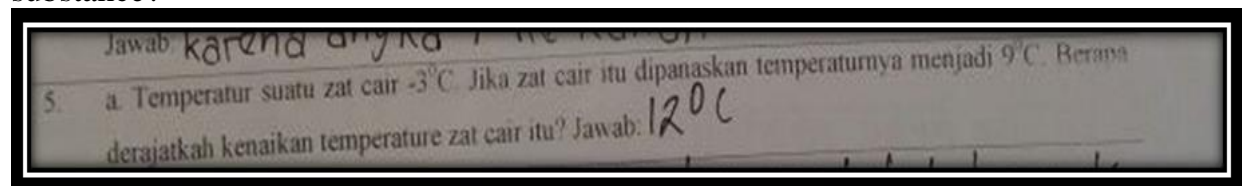

Figure 7

The Answer of Student 6 (S6) 
Based on the student's answer, it can be seen that he has been able to sequence the values of positive integers and also the value of negative integers from the smallest to the largest. The student is also able to answer the question of temperature rise from -3 to 9 using the number line. This is shown by the following interview transcript. ( $R$ is researcher).

$R:$ "Why is the result 12 ?" (pointing to the question number 5)

S6: "It is because it is increasing from -3 up to 9. I counted it by using the number line and it moves up to 12 times."

\section{DISCUSSION}

Bofferding (2014) states that there are five levels of students' mental models in understanding the concept of integers, i.e. the initial mental model, transition 1, synthetic mental model, transition 2, and the formal mental model. Bofferding (2014) developed the five levels of the mental model based on the mental model which was firstly developed by Vosniadou (1992) who divides the students' mental models in understanding the concept of the earth into three levels. In this article, researchers develop five levels of Bofferding's mental model (2014) into six levels of mental models by adding pre-initial levels prior to the initial mental model. This is based on research findings which indicate that of 40 students given test questions, there are four students who are not included in the five levels of Bofferding's mental model (2014).The following will be explained more about the students' mental model in understanding the concept of integers in Table 3.

Table 3

The Level of Students' Mental Model in Comprehending the Concept of Integers

\begin{tabular}{|c|c|}
\hline $\begin{array}{l}\text { The Level of } \\
\text { Mental Model }\end{array}$ & General Description \\
\hline $\begin{array}{l}\text { Pre-initial Mental } \\
\text { Model }\end{array}$ & $\begin{array}{ll}\text { - } & \text { Students do not know that the number on the left of one is zero. } \\
\text { - } & \text { Students only understand positive integers. }\end{array}$ \\
\hline $\begin{array}{l}\text { Initial Mental } \\
\text { Model }\end{array}$ & $\begin{array}{l}\text { - Students know that the number on the left of one is zero. } \\
\text { - Students consider the value of negative numbers as well as positive } \\
\text { numbers (students assume the numbers to the left of zero are the same as } \\
\text { positive integers). }\end{array}$ \\
\hline $\begin{array}{l}\text { Transitional } \\
\text { Mental Model } 1\end{array}$ & $\begin{array}{l}\text { - Students are able to compare the values of negative integers and } \\
\text { positive numbers (the value of positive integers is greater than negative } \\
\text { integers). } \\
\text { - Students cannot compare the value of two negative numbers. }\end{array}$ \\
\hline $\begin{array}{l}\text { Synthetic Mental } \\
\text { Model }\end{array}$ & - $\quad$ Students are able to compare the values of two negative numbers. \\
\hline $\begin{array}{l}\text { Transitional } \\
\text { Mental Model } 2\end{array}$ & $\begin{array}{l}\text { - Students have been able to compare two negative numbers but have } \\
\text { not been consistent in sorting negative integers. } \\
\text { - } \quad \text { Students are able to sequence positive integers. }\end{array}$ \\
\hline $\begin{array}{l}\text { Formal Mental } \\
\text { Model }\end{array}$ & $\begin{array}{l}\text { - Students are able to sort positive integers and negative integers } \\
\text { (students understand the positive and negative integer symmetry } \\
\text { properties). }\end{array}$ \\
\hline
\end{tabular}


Based on Table 2, the results show that there are six levels of students' mental models in understanding the concept of integers. The six levels are pre-initial mental models, initial mental models, transitional mental models 1 , synthetic mental models, transitional mental models 2, and formal mental models. Students at the pre-initial mental model level assume that the number consists of merely the natural number or the positive integer. The students have not understood that there are 'zeros' and negative integers. Avcu \& Durmaz (2011) state that students still have difficulty in sequencing the integers on the number line. In addition, students use positive integer reasoning to solve negative integer problems (Bofferding \& Enzinger, 2017). In fact, before the students know the integers and the whole numbers, the new primary school students understand the natural numbers (Hollings, 2014).

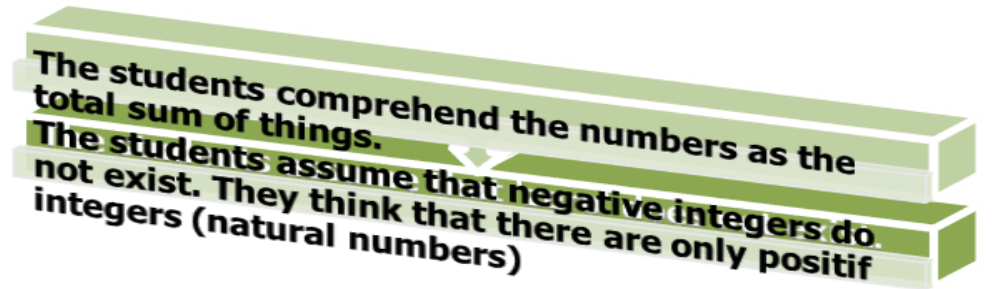

Figure 8

Students' Understanding of Pre-initial Mental Model

Students at the pre-initial mental model level consider numbers as something that is countable (e.g. one pencil, two apples, three books, etc.). The students do not see 'zero' as a number because they think that zero cannot be represented against the number of objects (Utami \& Parta, 2017 and Carpenter, et al., 2003). This can obstruct students from internalizing the meaning of arithmetic operations and building relationships between concepts in mathematics (Kiziltoprak \& Kose, 2017). Students tend to easily complete one arithmetic operation only (Vula, et al, 2017).

Students at the level of the initial mental model have already understood the zeros and positive integers. The students at this level consider that the value of the negative number is the same as the positive integers. Vosniadou \& Brewer (1992) state that students treat negative numbers like positive integers. Students at the mental model level do not notice the minus sign to the left of 'zero'. It is in line with Bishop, Lamb, Phillip, Schapelle, \& Whitacre (2011) and Wilcox (2008) who state that children labelled numbers before zero with their own notation. According to Bofferding (2014), the child treats a negative integer value just like a positive integer because the child views the minus sign simply as a subtraction operation.

Students at the level of the transitional mental model 1 have not been consistent in comparing the values of two numbers. They already understand that the value of a positive number is greater than the value of a negative number. Bofferding (2010) found that students tend to describe positive integers higher than negative integers. However, students at the level of the transitional mental model 1 still consider the treatment of negative integer values as well as positive integer values. This is in accordance with the results of Whitacre (2012), in which he states that students tend to interpret the value of 
negative integers as well as the value of positive integers. Stavy et al. (2002) state that the child already knows that there are negative integers before 'zero', but the child interprets the value of negative numbers which are far from the 'zero' are greater than the negative ones which are close to 'zero'.

Students at the level of the synthetic mental model have been consistent in comparing the values of two numbers. They already understand that the value of a positive number is greater than the value of the negative number and also have understood that the smaller the negative number the greater the value. This is in line with Shutler (2017) who states that when students understand the minus sign as a 'unary' meaning and not just 'binary', they will be able to compare two negative numbers.

Students at the level of the transitional mental model 2 have not been consistent in ordering the values of negative integers. They are able in sorting positive integers but still wrong in ordering the value of negative numbers. When a child is tested simultaneously to rank positive integer values and negative integers, the child still considers that the value of a negative integer equals to the value of a positive integer. Curtis, Okamoto, \& Weckbacher (2009) state that children able to compare two numbers correctly but they still get difficulty in ordering them.

Students at the formal mental model level are consistent in ordering the values of negative integers and positive integers. They are able to solve the problem by taking the initiative to create a number line. This is in line with the recommendation of the National Council of Teachers of Mathematics (2000) that students should use a number line to understand the value of negative numbers.

\section{CONCLUSION}

Based on the findings, the conclusion is that there are six levels of students' mental models in understanding the concept of integers. The six levels are pre-initial mental model, initial mental model, the first transitional mental model, synthetic mental model, the second transitional mental model, and formal mental model. The child's pre-initial mental model can be seen when the child assumes that the number in the left of 'one' is the same as the number in the right of 'one'. The child's initial mental model can be seen when the child thinks that the number in the left of 'zero' is the same as the number in the right of 'zero'. In other words, the child's initial mental model can be seen when the child considers the value of the negative number is the same as positive number.

A child's transition mental model can be seen when the child has not been consistent in comparing the values of two numbers. The child at the level of the transitional mental model 1 already understands that the value of a positive number is greater than the value of the negative number, but has not been able to compare the two negative numbers. The synthetic mental model of the child can be seen when the child is consistent in comparing the values of two numbers. He/she already understands that the value of a positive number is greater than the value of the negative number and also has understood that the smaller the negative number, the greater the value. 
A child's transitional mental model 2 can be seen when the child has not been consistent in ordering a negative integer number. The child at this level is able to order positive integers correctly but is still wrong in ordering a negative integer value. A child at the level of the formal mental model can be seen when the child is consistent in sorting negative integer values and positive integer values. A child at this level has been able to solve the problem by taking the initiative to create a number line.

\section{RECOMMENDATIONS}

Based on the research findings, it was found that there is a pre-initial mental model level prior to the initial mental model. The pre-initial mental model can be seen from children's information stored in their long-term memory before they are confronted with a particular concept. This can be seen before the child understands a negative integer and knows the 'zero' number, then the child understands a positive integer. For that, the researchers recommend further research to explore more deeply of how the formation of pre-initial mental models of children is. Does the child at the pre-initial mental model have symptoms of cognitive impairment? This is based on the research findings which reveal that children who are at the level of pre-initial mental models have the concept of numbers as the sum of objects.

\section{ACKNOWLEDGEMENTS}

The authors are very grateful to Director of Directorate of Research Service, Ministry of Research and Technology and Higher Education of the Republic of Indonesia on research funding.

\section{REFERENCES}

Abdullah, F.A. (2006). The pattern of physics problem-solving from the perspective of metacognition. Master Dissertation, University of Cambridge. http://people.pwf.cam.ac.ok/kst24/ResearchStudents/. Accessed on 5 January 2016.

Ahi, B. (2016). A study to determine the mental models in preschool children's conceptualization of a desert environment. International Electronic Journal of Elementary Education, 8(3), 333-350.

Akyüz, D., Stephan, M., \& Dixon, J. K. (2012). The role of the teacher in supporting imagery in understanding integers. Education and Science, 37(163), 268-282.

Barsalou, L.W. (1992). Cognitive Psychology: An Overview for Cognitive Scientist. Hillsdale., New Jersey: LEA (Lawrence Erlbaum Associates), 410 page.

Avcu, T., \& Durmaz, B. (2011). Tam sayılarla ilgili işlemlerde ilköğretim düzeyinde yapılan hatalar ve karşılaşılan zorluklar. 2nd International Conference on New Trends in Education and Their Implications. 27-29 April, Antalya-Turkey.

Bishop, J.P., Lamb, L.L., Philip, R.A., Whitache, I., Schappelle, B.P., \& Lewis, M.L. (2014). Obstacles and affordances for integer reasoning: an analysis of children's thinking and the history of mathematics. Journal for Research in Mathematics Education, 45 (1): 19-61. 
Bishop, J.P., Lamb, L.L., Philipp, R.A., Whitacre, I. \& Schappelle, B.P. (2014). Using order to reason about negative numbers: the case of Violet. Educ Stud Math, 86: 39-59.

Bishop, J. P., Lamb, L. L. C., Philipp, R. A., Schapelle, B. P., \& Whitacre, I. (2011). First graders outwit a famous mathematician. Teaching Children Mathematics, 17(6), 350-358.

Bofferding, L. (2014). Negative integer understanding: characterizing first graders' mental models. Journal for Research in Mathematics Education, 45 (2): 194-245.

Bofferding, L. \& Enzinger, N.W. (2017). Subtraction involving negative numbers: Connecting to whole number reasoning. The Mathematics Enthusiast, 14 (1, 2\&3), 241-262.

Bofferding, L. (2010). Addition and subtraction with negatives: acknowledging the multiple meanings of the minus sign. In P. Brosnan, D. Erchick, \& L. Flevares (Eds.), Proceedings of the 32nd Annual Meeting of the North American Chapter of the International Group for the Psychology of Mathematics Education (Vol. VI, pp. 703710). Columbus, OH.

Carpenter, T. P., Franke, M. L., \& Levi, L. (2003). Thinking Mathematically: Integrating arithmetic and algebra in the elementary school. Portsmouth, $\mathrm{NH}$ : Heinemann.

Chiras, A. (2008). Day/night cycle: mental models of primary school children. Science Education International, 19(1): 65-83.

Chittleborough, G.D. and Treagust D. F. (2007). The modeling ability of non-major chemistry students and their understanding of the sub-microscopic level. Chem. Educ. Res. Pract., 8: 274-292.

Coll, R.K., (2008). Chemistry learners' preferred mental models for chemical bonding. Journal of Turkish Science Education, 5 (1): 22 - 47.

Curtis, R., Okamoto, Y., \& Weckbacher, L. M. (2009). Preschoolers' use of count information to judge relative quantity. Early Childhood Research Quarterly, 24(3), 325-336. doi:10.1016/j.ecresq.2009.04.003.

Enzinger, N. \& Tobias, J.M. (2015). Preservice teachers' temperature stories for integer addition and subtraction. Proceedings of 39th Psychology of Mathematics Education conference, Vol. 4, pp. 289-296. Hobart, Australia: PME.

Golafshani, N. (2003). Understanding reliability and validity in qualitative research. The qualitative report, 8(4), 597-606.

Guzel, B.Y. \& Adadan, E., (2013). Use of multiple representations in developing preservice chemistry teachers' understanding of the structure of matter. International Journal of Environmental \& Science Education, 8 (1): 109-130.

Hollings. C. (2014). Embedding semigroups in groups: not as simple as it might seem. Archive for History of Exact Sciences 68(5), 641-692.

Jaber, L.Z. and Boujaoude, S. (2012). A macro-micro-symbolic teaching to promote relational understanding of chemical reactions. International Journal of Science Education, 34 (7): 973-998. 
Karadeniz, M.H., Kaya, T.B., \& Bozkus, S. (2017). Explanations of prospective middle school mathematics teachers for potential misconceptions on the concept of symmetry. International Electronic Journal of Elementary Education, 10(1), 71-82.

Karantzis, I. (2010). Mental arithmetic calculation in the addition and subtraction of two-digit numbers: the case of third and fourth-grade elementary school pupils. International Journal of Mathematics in Education, 3, 3-24.

Kaya, D., Izgiol, D., \& Kesan, C. (2014). The investigation of elementary mathematics teacher candidates' problem-solving skills according to various variables. International Electronic Journal of Elementary Education, 6(2), 295-314.

Kiziltoprak, A. \& Kose, N.Y. (2017). Relational thinking: the bridge between arithmetic and algebra. International Electronic Journal of Elementary Education, 10(1), 131-145.

Mathison, S. (1988). Why triangulate? Educational Researcher, 17(2), 13-17.

Mardiyana, S., Susiswo, \& Hidayanto, E. (2016). Pemahaman instrumental dan relasional mahasiswa dalam menyelesaikan masalah turunan (Understanding of students' instrumental and relational in solving problems), Prosiding Seminar Matematika dan Pendidikan Matematika, 67-76. 16 November 2016. FKIP UNS. Surakarta.

National Council of Teachers of Mathematics. (2000). Principles and standards for school mathematics. Reston, VA: Author. Retrieved from http://www.nctm.org/standards/content.aspx?id=26792

Özdemir, G \& Clark, D.B. (2007). An overview of conceptual change theories. Eurasia Journal of Mathematics, Science \& Technology Education, 3(4), 351-361.

Park, E.J. \& Light, G. (2009). Identifying atomic structure as a threshold concept: student mental models and troublesomeness. International Journal of Science Education, 31 (2): 233-258.

Sa'dijah, C. (2009). Asesmen kinerja dalam pembelajaran matematika (Performance Assessment in Mathematics Instruction). Jurnal Pendidikan Inovatif, 4 (2), 92-95.

Senge, P.M. (2004). The fifth discipline. the art and practice of the learning organization. New York: Doubleday Dell Publishing Group, Inc. 405 pages.

Shutler, P.M. (2017). A symbolical approach to negative numbers. The Mathematics Enthusiast, 14 (1) 1, 2, \& 3, 206-240.

Solaz-Portolẻs, J.J., and Lopez, V.S. (2007). Representations in problem-solving in science: directions for practice. Asia-Pacific Forum on Science Learning and Teaching, 8 (2). Article 4 (December 2007).

Stavy, R., Tsamir, P., \& Tirosh, D. (2002). Intuitive rules: the case of "More A - More B.” In M. Limón \& L. Mason (Eds.), Reconsidering conceptual change: Issues in theory and practice (pp. 217-231). New York, NY: Kluwer Academic.

Subanji. (2015). Teori kesalahan konstruksi konsep dan pemecahan masalah matematika (The theory of concept construction error and mathematics problem solving). Malang: Universitas Negeri Malang. 
Sumantri, M.S. \& Satriani, R. (2016). The effect of formative testing and self-directed learning on mathematics learning outcomes. International Electronic Journal of Elementary Education, 8(3), 507-524.

Sunyono, Leny Y, \& Muslimin I. (2011). Model mental mahasiswa tahun pertama dalam mengenal konsep stoikiometri; studi pendahuluan pada mahasiswa ps. pendidikan kimia FKIP Universitas Lampung. ("first-year student's mental models in understanding concepts stoichiometry; preliminary study on chemical education student, Faculty of Teacher Training and Education, University of Lampung"), in Prosiding Seminar Nasional V. 6 Juli 2011. Universitas Islam Indonesia. Yogyakarta.

Sunyono, Yuanita, L., \& Ibrahim, M. (2015). Mental models of students on stoichiometry concept in learning by method based on multiple representations. The Online Journal of New Horizons in Education, 5(2), 31-45.

Sunyono \& Yulianti, D. (2015). Introductory study on student's mental models in understanding the concept of atomic structure (case study on high school students in lampung indonesia). The Online Journal of New Horizons in Education, 5(4), 41-50.

Tasker, R. \& Dalton, R. (2006). Research into Practice: visualization of the molecular world using animations. Chem. Educ. Res. Prac, $7: 141-159$.

Ural A. \& Buldur. (2016). 7th-grade students' understandings of negative integer. Journal of Studies in Education, 6 (2): 170-179.

Utami, A.D. \& Parta, I. N. (2017). Sistem representasi internal siswa dalam membangun konsepsi bilangan bulat negatif (Students' internal representation system in constructing negative integer conception). Prosiding Seminar Nasional Pendidikan Matematika, Mengembangkan Kompetensi Strategis dan Berpikir Matematis di Abad 21, 565- 573. 8 April 2017. Universitas Negeri Malang. Malang.

Vlassis, J. (2008). The role of mathematical symbols in the development of number conceptualization: the case of the minus sign. Philosophical Psychology, 21(4), 555-570.

Vosniadou, S., \& Brewer, W. F. (1992). Mental models of the earth: a study of conceptual change in childhood. Cognitive Psychology, 24(4), 535-585.

Vula, E., Avdyli, R., Berisha, V., Saqipi, B., \& Elezi, S. (2017). The impact of metacognitive strategies and self-regulating processes of solving math word problems. International Electronic Journal of Elementary Education, 10(1), 49-59.

Wang, C.Y. (2007). The role of mental-modeling ability, content knowledge, and mental models in general chemistry students' understanding about molecular polari. Dissertation for the Doctor Degree of Philosophy in the Graduate School of the University of Missouri. Columbia.

Whitacre, I., Bishop, J. P., Lamb, L. L. C., Philipp, R. A., Schappelle, B. P. \& Lewis, M. L. (2012). What sense do children make of negative dollars? In L. R. Van Zoest, J. Lo, \& J. L. Kratky (Eds.), Proceedings of the 34th Annual Meeting of the North American Chapter of the International Group for the Psychology of Mathematics Education (pp. 958-964).

Wilcox, V. (2008). Questioning zero and negative numbers. Teaching Children Mathematics, 15(4), 202-206. 